\title{
PRELIMINARY RESULTS OF THE GROUND PENETRATING RADAR (GPR) PROSPECTION IN THE AREA OF THE PREHISTORIC FLINT MINE BOROWNIA, SOUTHEASTERN POLAND
}

\author{
Radosław Mieszkowski ${ }^{1}$, Fabian Welc ${ }^{2}$, Janusz Budziszewski ${ }^{2}$, Witold Migal ${ }^{3}$, Anna Bąkowska ${ }^{1}$ \\ ${ }^{1}$ Institute of Hydrology and Engineering Geology, Faculty of Geology, University of Warsaw, Żwirki i Wigury, \\ 93, 02-089 Warsaw, Poland \\ ${ }^{2}$ Institute of Archaeology of the Cardinal Wyszyński University in Warsaw, Wóycickiego 1/3, building 23, \\ 01-938Warsaw,Poland,e-mail:f.welc@uksw.edu.pl \\ ${ }^{3}$ State Archeological Museum in Warsaw, Dtuga 52,00-241 Warsaw, Poland
}

\begin{abstract}
Preliminary results of GPR field prospection carried out in the area of the prehistoric mining field Borownia (Ćmielów, Ostrowiec Świętokrzyski District) are presented. This mining field forms a belt (30-50 m wide and $700 \mathrm{~m}$ long), starting from the valley edge of the Kamienna River southeastwards. Southeastern and western parts of the site have preserved the original post-exploitation relief. Geology of the Borownia mining field was examined and acquired radiograms revealed three distinct zones of anomaly concentrations. The central zone (B) is clearly a fragment of the prehistoric mining field, confirmed not only by the GPR sounding but also by archaeological surveys. The other two zones have not yet been investigated in detail but their surface and archaeological examination may determine only whether their underground structures are natural or have been created by humans. Data obtained during the GPR prospection at the Borownia archaeological site confirmed usefulness of 100, 250 and $500 \mathrm{MHz}$ antennas. The relatively large depth range and good resolution are due to favorable geological conditions.
\end{abstract}

Key words: ground penetrating radar, archaeological site, prehistoric flint mine, Borownia, Poland.

Manuscript received 8 June 2014, accepted 4 November 2014

\section{INTRODUCTION}

The key objectives of the project carried out in the Borownia prehistoric mining field included possibility of application of the ground penetrating radar (GPR) method in non-invasive archaeological site prospection, especially in areas of prehistoric flint mines. Another important issue was to develop the most effective procedure for data processing and interpretation. GPR survey at Borownia was performed in 2010-2013. The authors used also results of GPR measurements, collected in 2011 by the private company Proton-Archeo for the Scientific Association of Polish Archaeologists (SNAP) as part of a grant awarded by the Polish Ministry of Culture and National Heritage.

\section{METHODOLOGY}

Dynamic development and wide application of georadar (Ground Penetrating Radar), both for military and civilian use, has been noted after the Second World War. Since the 80 s, many devices of this kind were also successfully used in geological research as well as in non-invasive archaeological prospection (Conyers, 2004). GPR method is based on the emission of electromagnetic waves (EM) of short or ultrashort radio waves of the frequencies from $50 \mathrm{MHz}$ to 1.6 $\mathrm{GHz}$, registration of pulses reflected from lithological boundaries and layers characterized by specific permittivity (dielectric constant) and electrical resistance, depending on the lithology and degree of saturation of geological formations. For example, in high conductive sediments, dumping of EM waves is significant and wave propagation is relatively small. A contrast of dielectric properties of two media determines mainly a power of the reflected signal from a boundary and consequently, intensity of reflections recorded on echograms (radiograms).

GPR prospecting range is dependent on two main factors: the nominal frequency of the transmitting antenna and the electrical resistance of the tested soil or other sediments. The smaller frequency antenna gives higher depth of penetration and at the same time the lower resolution. In the worst case, particularly in low-resistance deposits (e.g. clay, silt), dumping of electromagnetic waves may be so high that GPR prospecting depth may be reduced to a few meters or even several centimeters (Conyers, 2004; Karczewski, 2007). 


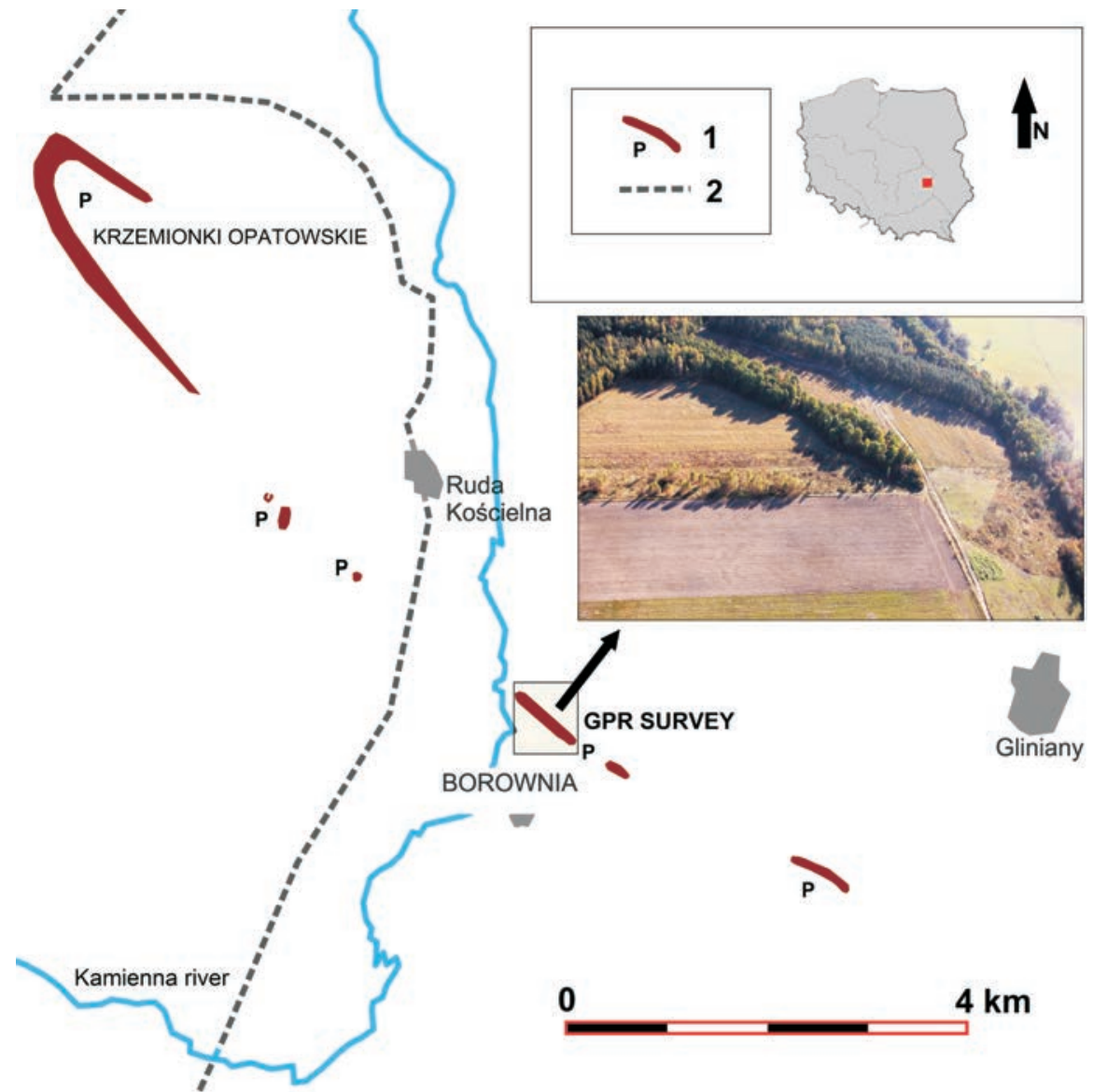

Fig. 1. Location of the prehistoric flint mine Borownia in northeastern Permian-Mesozoic margin of the Holy Cross Mountains. 1 - prehistoric flint mine, 2 - main road.
The mining field "Borownia" forms a belt $(30-50 \mathrm{~m}$ wide and $700 \mathrm{~m}$ long), starting from the valley closeup of the Kamienna river towards southeast (Budziszewski and Michniak, 1989). Southeastern and western part of the site (about $100 \mathrm{~m}$ long) remains original post-exploitation relief, manifested by concentrations of small dumps of limestone debris around circular depressions that indicated individual shafts. Debris dumps are 5 to $8 \mathrm{~m}$ in diameter. The area is forested at present, what has hampered significantly surface observations until recently. The other sections of the western part of the site have been used for farming during the last century and it has resulted in total leveling of the original post-exploitation relief.

Numerous prehistoric flint toll fragments, mainly flakes (suggesting presence of flint workshops) were found in the area neighboring directly to the strip with preserved covering post-exploitation relief(Budziszewski and Michniak, 1989). Analysis of archaeological materials, both in the mining field and in adjacent areas proved that bifacial axe roughouts of Early Bronze Age of the Mierzanowice culture predominated (Balcer and Kowalski, 1978).

During geophysical survey carried out in the prehistoric field mine at Borownia, the radar system of RAMAC GPR produced by Mala Geoscience (Sweden), was used. Prospection was carried out using shielded antennas of the nominal frequency of EM wave equal to 100, 250 and $500 \mathrm{MHz}$ respectively. The device was equipped with a computer with RAMAC Ground Vision software designed for data acquisition directly in the field. The received radiograms were processed using Reflexw-Win software designed by Sendmeier Software (Germany).

Display of each GPR previously processed profile is presented on radiograms. Actual distance is plotted on a horizontal axis (y) in meters that corresponds to a length of each profile. On a vertical axis (x) there is a depth scale plotted on the right side, while a time scale in $\mathrm{ns} / \mathrm{m}$ is on the left.

\section{GEOLOGICAL STRUCTURE AND PREVIOUS STUDIES OF THE PREHISTORIC MINING FIELD AT BOROWNIA}

The mining field "Borownia" at Ruda Kościelna (Ćmielów, Ostrowiec Świętokszyski District) belongs to a complex of prehistoric mines of the Upper Jurassic banded flint, located in the northeastern Permian-Mesozoic margin of the Holy Cross Mountains (Fig. 1). This site was discovered during field works by S. Krukowski and J. Samsonowicz in September 1921 (Krukowski, 1921).
The Borownia site is located in a marginal zone of the southwestern limb of the Magon-Folwarczysko syncline composed of the Upper Jurassic pelitic, marly, oolitic and organodetrital limestones. Pelitic and marly limestones are very thick and vary in terms of facies. They are both mediumlayered, slabby and soft chalky ones, as well as detrital, strongly diagenetically altered, bioclastic and pelitic in fragments (Romanek, 1994; cf. also Samsonowicz, 1934a). The bed of oolitic and organodetrital limestone occurs at the top of the Jurassic formation in the Ostrowiec Świętokrzyski area. There are mainly ooliths of pelitic matrix in its lower part. In the upper part there are mostly limestones, composed mainly of detrital material of varying origin. Banded flint and chocolate flint occur in these layers. This series is about $35 \mathrm{~m}$ thick (Romanek, 1994). Thus, the Upper Oxfordian beds, composed of pelitic and oolitic limestones form a medium for banded flint layers, not only at Borownia but also in the neighboring Krzemionki Opatowskie prehistoric flint mine (Samsonowicz, 1934b).

From our point of view, an important issue is a number of flint levels and their stratigraphic setting (Budziszewski, 2008). Jan Samsonowicz, the discoverer of the Borownia mining field, postulated in 1930s that banded flints are located $20 \mathrm{~m}$ below the characteristic chocolate flint layer, in a series of limestones approximately $30-35 \mathrm{~m}$ thick and in a constant stratigraphic position covering the Upper Jurassic pe- 


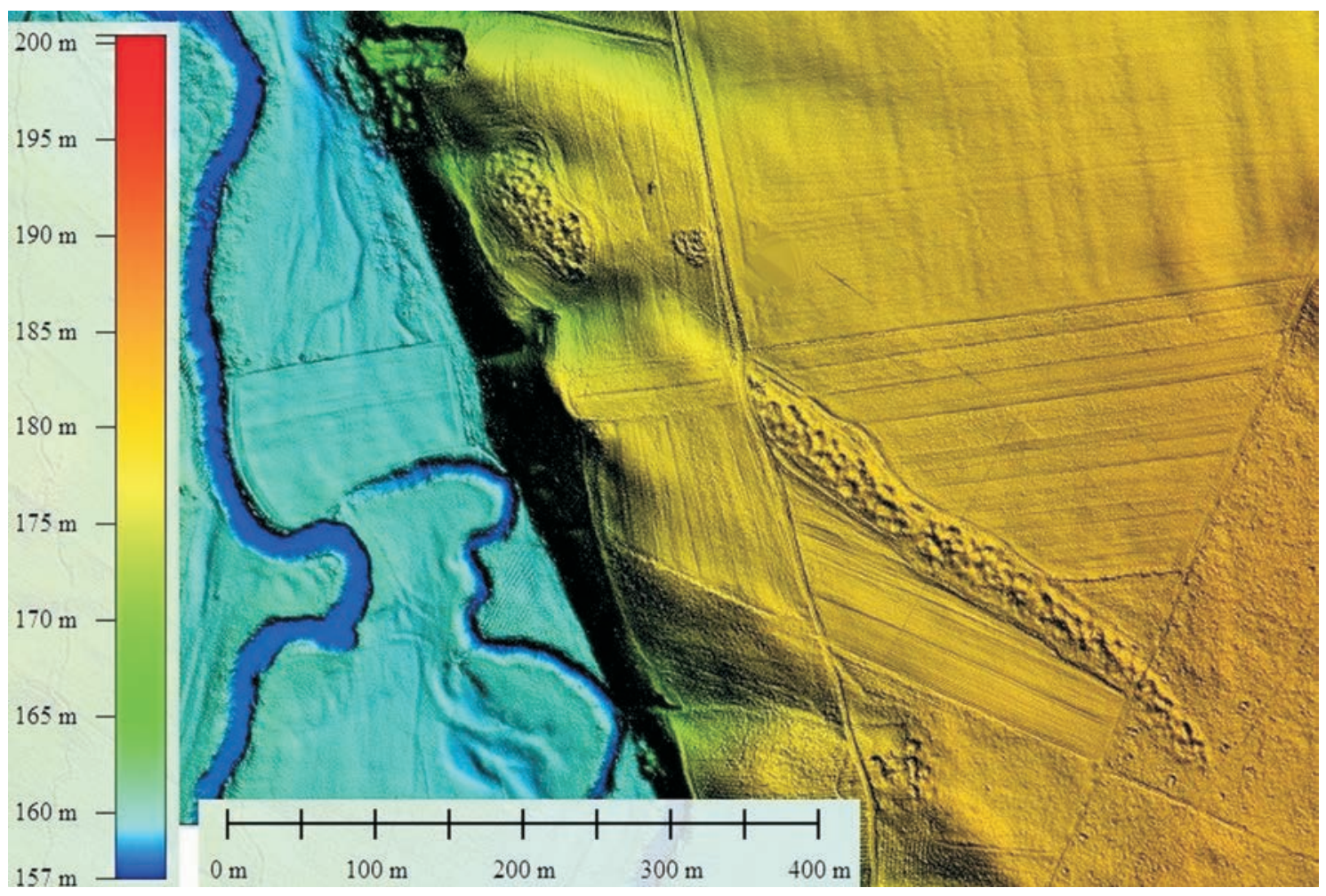

Fig. 2. Digital terrain model of the Borownia prehistoric flint mine, based on airborne laser scanning (ALS).

riod (Samsonowicz, 1934a). Recent investigations confirm these suggestions, according to which both flint levels are separated by a series of layered pelitic limestones, about $20 \mathrm{~m}$ thick (Budzi- szewski, 2008).

The doubled layer of banded flint is a significant correlation level from both geological and archaeological point of view (Gutowski, 1998). It is reflected by the fact that so far all documented traces of prehistoric exploitation of banded flint and geological sites studied nowadays are the sites with a single flint level (cf. Fig. 1), from a large mining field at Krzemionki Opatowskie, continuing towards Ruda Kościelna (Księża Rola Mała, Księża Rola Duża, Ostroga and Borownia mining fields), Łysowody (Krunio site) and ending at Wojciechówka (Korycizna site).

The banded flint, exploited in prehistorical times, forms usually strongly flattened, cake-like and cob-like nodules of considerable sizes. It is important that the two flint layers do not keep the same distance from each other but it increases northwestwards, therefore it is about $80 \mathrm{~cm}$ in Zawichost on the Vistula, but exceeds to $2.5 \mathrm{~m}$ at Krzemionki Opatowskie (Budziszewski and Michniak, 1989).

Jurassic rocks in the Ostrowiec Świętokrzyski area form the third and the last structural stage. Rock layers are usually slightly inclined northeast, but dips can reach a right angle in dislocation areas, due to the Laramean Phase of the Alpine orogeny. The Magon-Folwarczysko syncline was formed in the same time (Jaroszewski, 1972). A lithological sequence with two layers of banded flint was documented in the Śródborze quarry, $320 \mathrm{~m}$ from the Korycizna prehistoric mining field. These layers contact with rock beds running NWW - SEE and dipping about 15 degrees to the north
(Budziszewski and Michniak, 1989). In the Krzemionki area dips of rock layers are slightly smaller, averaging from 4 to about 10 degrees (Borkowski and Michniak, 1992).

The area of the Borownia site and the whole belt of banded flint outcrops within the Magoń-Folwarczysko syncline was scanned in 2011 using airborne laser scanning (ALS). The received accurate model of the relief of the area is used in this paper (Fig. 2). A major issue of the geophysical project initiated in 2010 (Welc et al., 2014) was to determine extent and type of mining objects in the area with leveled post-exploitation relief and reconstruction of mining methods used at the site. The ground-penetrating radar was used for this purpose and the results obtained are discussed in details in the following part of the paper.

A surprising and yet difficult to explain is the fact that the Digital Terrain Model, based on airborne laser scanning (ALS), presents exact course of Jurassic limestone beds, although they are covered with a thin (2-3 m) mantle of Quaternary deposits, what should result in leveling of the ground and hiding a relief of the eroded bedrock in the area (cf. Fig. 2). There are also very well distinct small folds on the digital model, marking limestone layers of varying resistance, invisible on a ground surface. In this situation, eroded layers and any disruptions in their course that reveal even minor tectonic faults are easier to be identified. This allows specifying and verifying a number of existing views on geological structure and origin of the Magon-Folwarczysko syncline.

The first GPR survey at Borownia in 2010 was focused on determination how mineshafts and galleries hewn in limestone are visible on GPR image (Boubaki et al., 2012). The carbonate rocks are not highly absorbing EM waves in gen- 


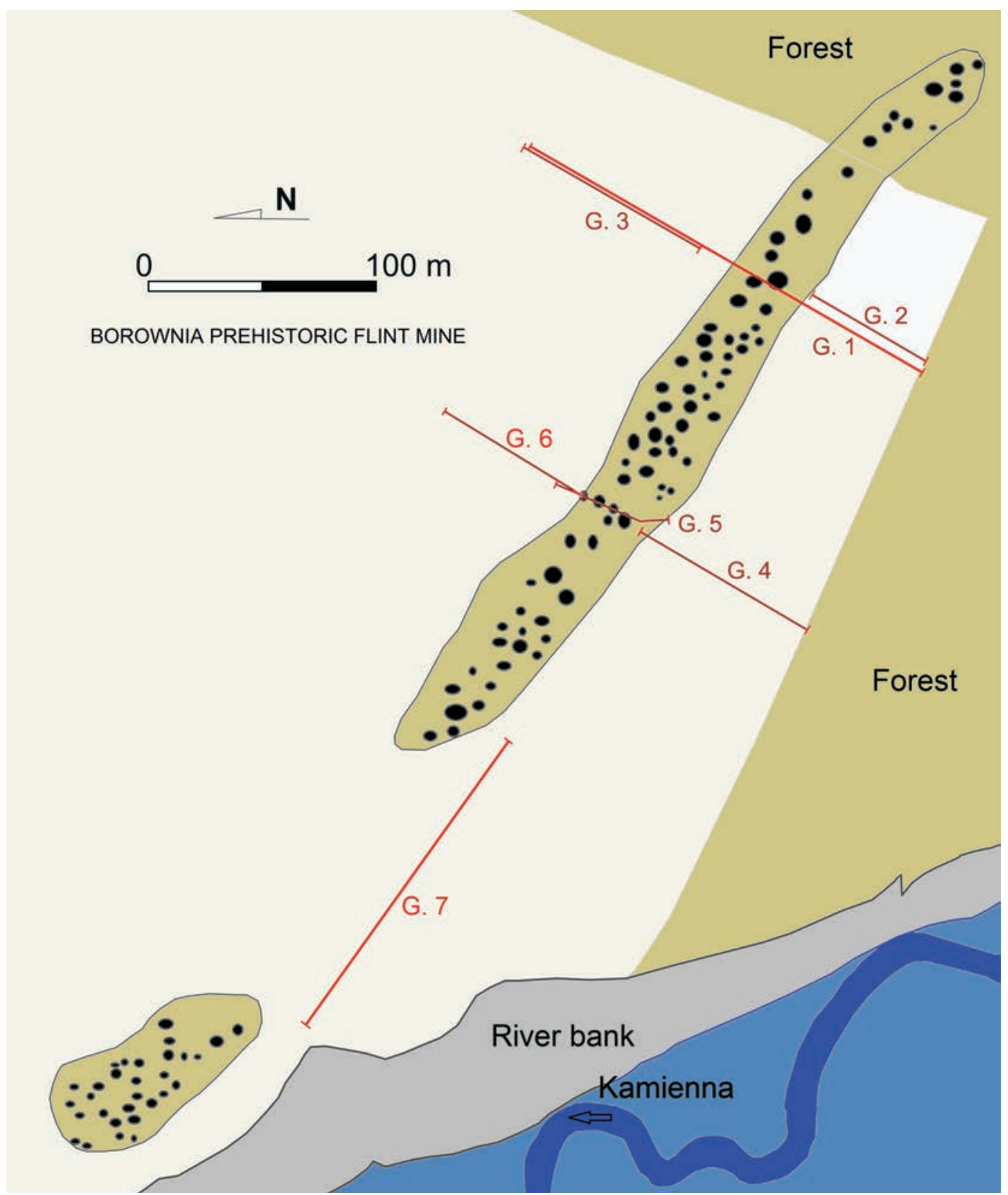

Fig. 3. Plan of the GPR prospection at Borownia using shielded antennas of the nominal frequencies of 100, 250 and $500 \mathrm{MHz}$, based on the digital terrain model (ALS). Individual GPR profiles are indicated in red.

eral. The mineshafts are in contrast usually filled with limestone debris, thus they emit strong reflections, i.e. anomalous zones are clearly defined on radiograms by set of characteristic hyperbolas. They are due to significant contrast in electric properties of solid rock and air partially filling the structure, among others the voids in poorly compacted debris. The dielectric constant and conductivity for limestone are respectively $4-8$ and $0.5-2 \mathrm{~ms} / \mathrm{m}$, while for the air they are 1 and 0 $\mathrm{ms} / \mathrm{m}$ (Davis and Annan 1989).

\section{RESULTS}

GPR prospection at Borownia was carried out using shielded antennas of nominal frequencies 100, 250 and 500 $\mathrm{MHz}$. The whole prospection comprised over 100 profiles, among which only a few those are presented in detail that clearly reveal geology of the area. Results from parallel profiles, carried out in 2011, have been already partly discussed by Boubaki et al. (2012).

The most important for interpretation were the profiles conducted by $250 \mathrm{MHz}$ antennas that were transverse to a course of the wooded part of the Borownia mining field with well-preserved post-exploitation relief (Fig. 3: G. 1). Acquired profiles were approximately $180 \mathrm{~m}$ long and revealed geological structure of the study area and degree of its transformation as result of intentional human activity.

Processed radiograms of 100 and $250 \mathrm{MHz}$ antennas (going from the top directly below the soil layer) indicated glacial sediments about 1.5-2 m thick that consisted mainly of glaciofluvial sands and gravels of the Odranian Glaciation (Roma- 
(1).
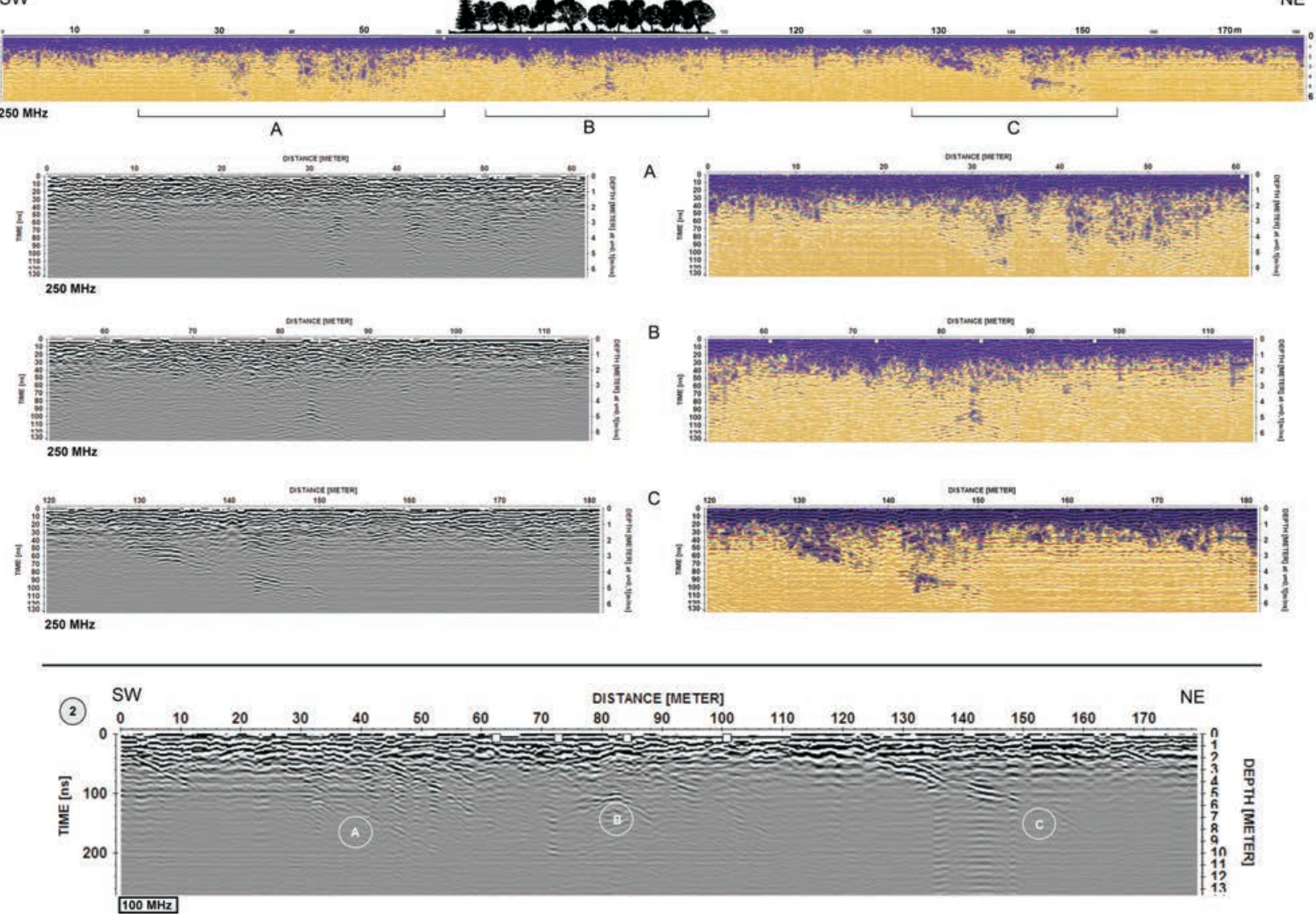

Fig. 4. Echograms from the southeastern part of the prehistoric mine field at Borownia. 1 - profile G. 1, antenna $250 \mathrm{MHz}$ (with close up of particular sections); 2 - profile G. 1, antenna $100 \mathrm{MHz}$.

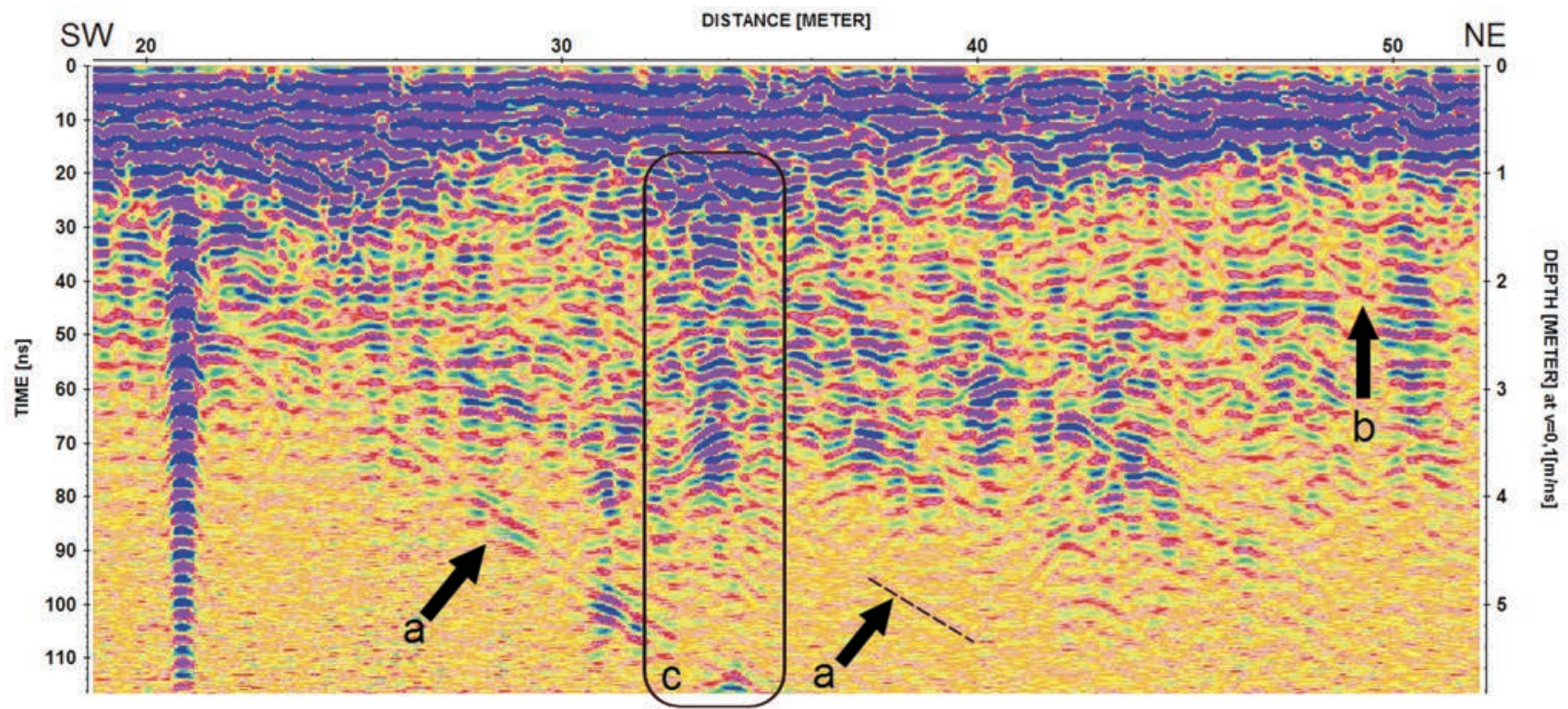

Fig. 5. Fragment of the echogram G. 2, antenna $500 \mathrm{MHz}$. a-lithological boundaries (stratification), b-eroded top of limestone massif, $\mathrm{c}-$ karst well?

nek, 1994), strongly affected by human activity (Fig. 4). Quaternary deposits were underlain by numerous diagonal reflective surfaces, caused by reflection of EM waves from lithological boundaries (rock layers). Their relatively steep inclination was apparent due to the depth scale effect. In fact, it could be estimated that this angle was about 5-10 degrees northeasterly, what seemed to be correlated with dip of the rock layers identified at Krzemionki Opatowskie (Borkowski and Michniak, 1992; Borkowski, 1995). 

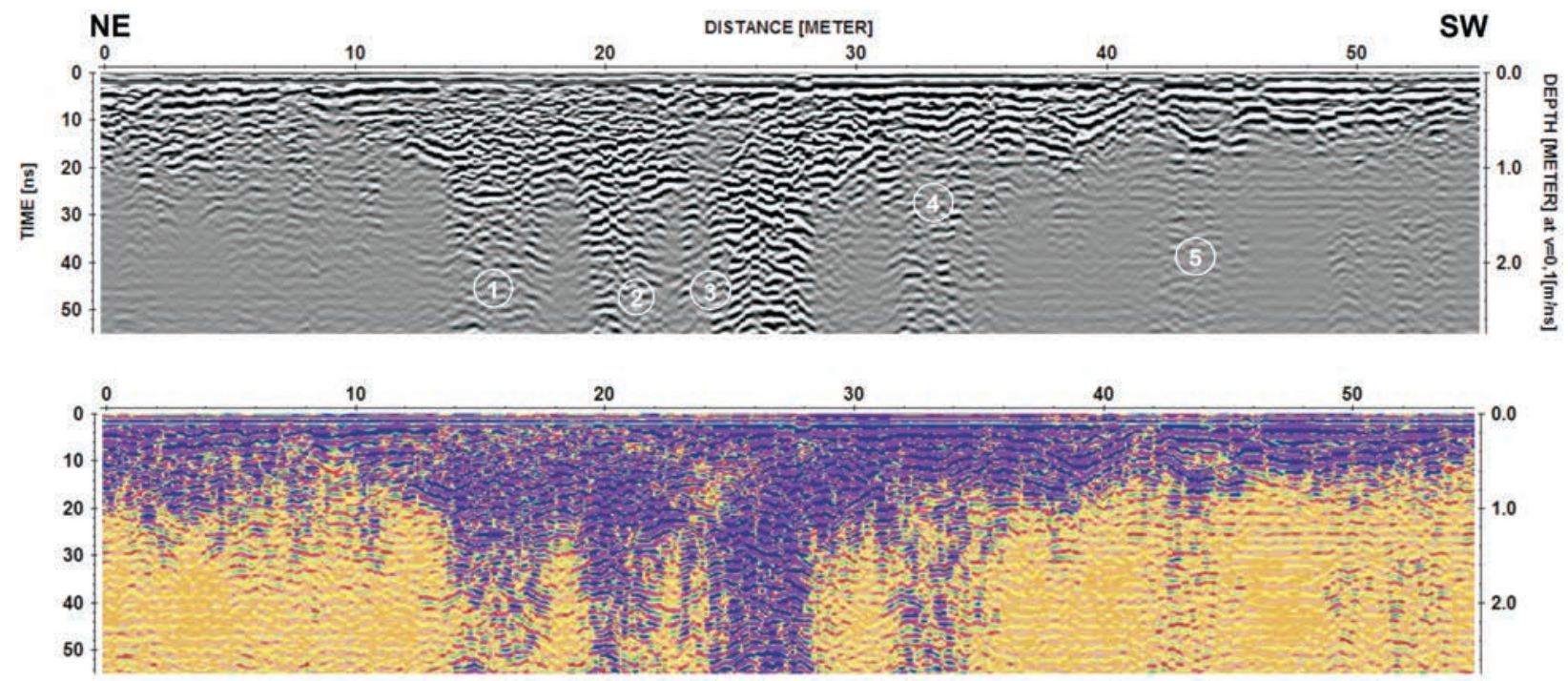

Fig. 6. Echogram G. 5, antenna $500 \mathrm{MHz}$. Outlines (echoes) of several mineshafts (nos 1-5) are very well visible.

The radiograms of 250 and $100 \mathrm{MHz}$ antennas between 20 and $60 \mathrm{~m}$ (zone A) indicated concentrations of anomalies, with numerous diffraction hyperbolas generated by underground structures (Fig. 4: 1A). Due to completely flattened surface relief in this place, it a correct interpretation was very difficult. Karst wells, chimneys and cavities, as well as structures of anthropogenic origin (Fig. 5) could generate those anomalies. If there were remains of prehistoric mining, they would have been entirely different in character than in zone B, described below. They could be assumed to have been shallow pit mines.

Karst phenomena are quite common in the Holy Cross Mountains and in its northeastern Mesozoic margin. They are mainly developed in Devonian and Upper Jurassic limestones. Devonian karst has large cavities and underground caves. Jurassic karst is typical for its more rare caves and a lack of surface waters, because of underground drainage through a system of fissures and karst wells. These structures occur sometimes very regularly, close to a circle in a horizontal section, especially the so-called flow wells with varied diameter and depth ranges from several to tens of meters (Klimaszewski, 1978)

The central part of the Borownia mining field is clearly distinct in morphology of the area through the non-degraded post-exploitation relief, currently forested (Figs 2, 3). The area was marked with $\mathrm{B}$ signature on analyzed radiograms (Fig. 4: 1B). The radiogram G. 5, acquired in this part of the mining field using $500 \mathrm{MHz}$ antenna, revealed concentration of anomalies caused by prehistoric mine shafts, outlines of which are clearly visible not only in GPR images but also on the surface as oval hollows surrounded by debris dumps described above (Fig. 6).

The profile G.1 (100 MHz) and G1 (250 MHz) acquired in zone $B$ presents also structures similar to those described above (Fig. 4: 1B, 2B). They seem to reflect the shafts to 5-6 m deep. They are probably so-called pillar and niche mines, which had in their lower part the characteristic exploration niches of different height and length, but not exceeding a few meters (cf. Borkowski, 2000). Roofs of excavation passages and niches are clearly visible on radiograms as diffraction hyperbolas with dif- ferent sloped shoulders, due to diverse speed of EM wave propagation in limestone massif at Borownia (Fig. 4: 1B).

In the area of the Borownia mining field the banded flint consisting of two parallel layers was exploited, similarly as at Krzemionki Opatowskie (Sałaciński and Michniak, 1992). It is confirmed by the radiogram G.7 in the western part of the studied area, acquired using $500 \mathrm{MHz}$ antenna. This profile was marked out parallel to the longitudinal axis of the mining field (Fig. 7). The processed radiogram between 1 and $30 \mathrm{~m}$ (at depth of approximately $6 \mathrm{~m}$ ) revealed an echo of a lithological boundary with its partial reflection and much weaker echo (approximately $2 \mathrm{~m}$ below) reflective of another layer (Fig. 7). Above these layers, there was a group of anomalies generated by the mining shafts. The echo was presumably derived from a double flint layer. This assumption was confirmed by the fact, that a top of the upper layer was clearly corrugated due to presence of objects of considerable size and different lithology (above $1 \mathrm{~m}$ in diameter), being probably flint nodules that generated characteristic diffraction hyperbolas in a radiogram (Fig. 7: a).

Radiographs acquired from 100 and $250 \mathrm{MHz}$ antennas between 125 and $150 \mathrm{~m}$ (zone C) revealed a clearly visible diagonal reflective zone (Fig. 4: 1C, 2C), very similar to the top flint layer captured on the radiogram G.7 (Fig. 7, a). The analyzed layer was found not to be straight, but it was slightly waved due to presence of objects of different diameter and lithological composition (presumably flint nodules), in comparison to the limestone background. Their probable presence would be contrary to the knowledge on occurrence of flint in the examined area (Fig. 8). Directly above the top of this layer there were abundant anomalies that could be interpreted as echo of karst structures or as prehistoric mine shafts occurring at a few meters depth (Fig. 8, the area framed). Additional GPR measurements and detailed study of the surface are still required for full understanding of these anomalies.

The radiographs G.4 and G.6, obtained using $500 \mathrm{MHz}$ antenna, revealed almost identical distribution of three zones of anomalies. The central zone (B) contained flint layers exploited in prehistorical times (Figs 9, 10). 


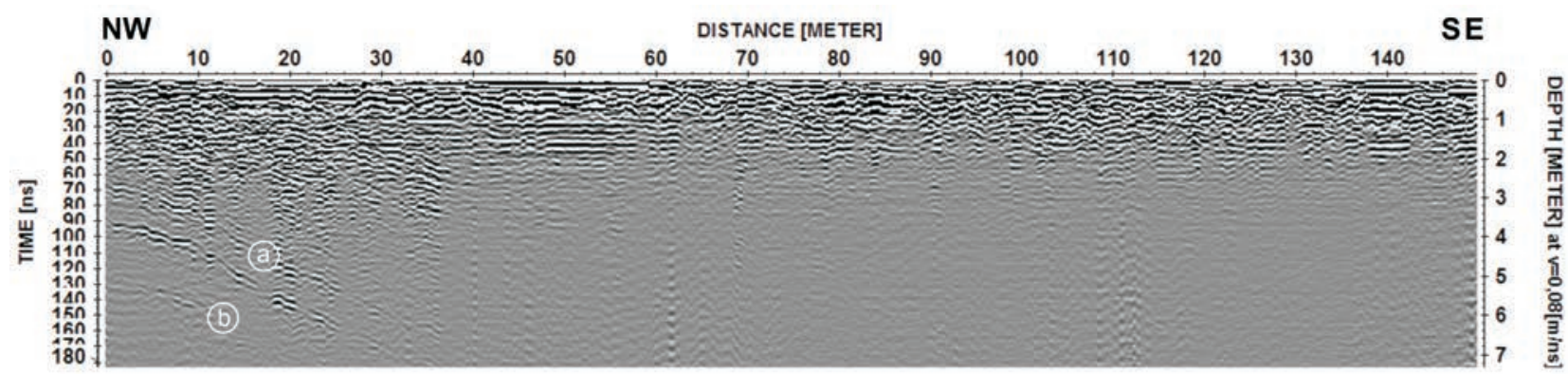

DISTANCE [METER]
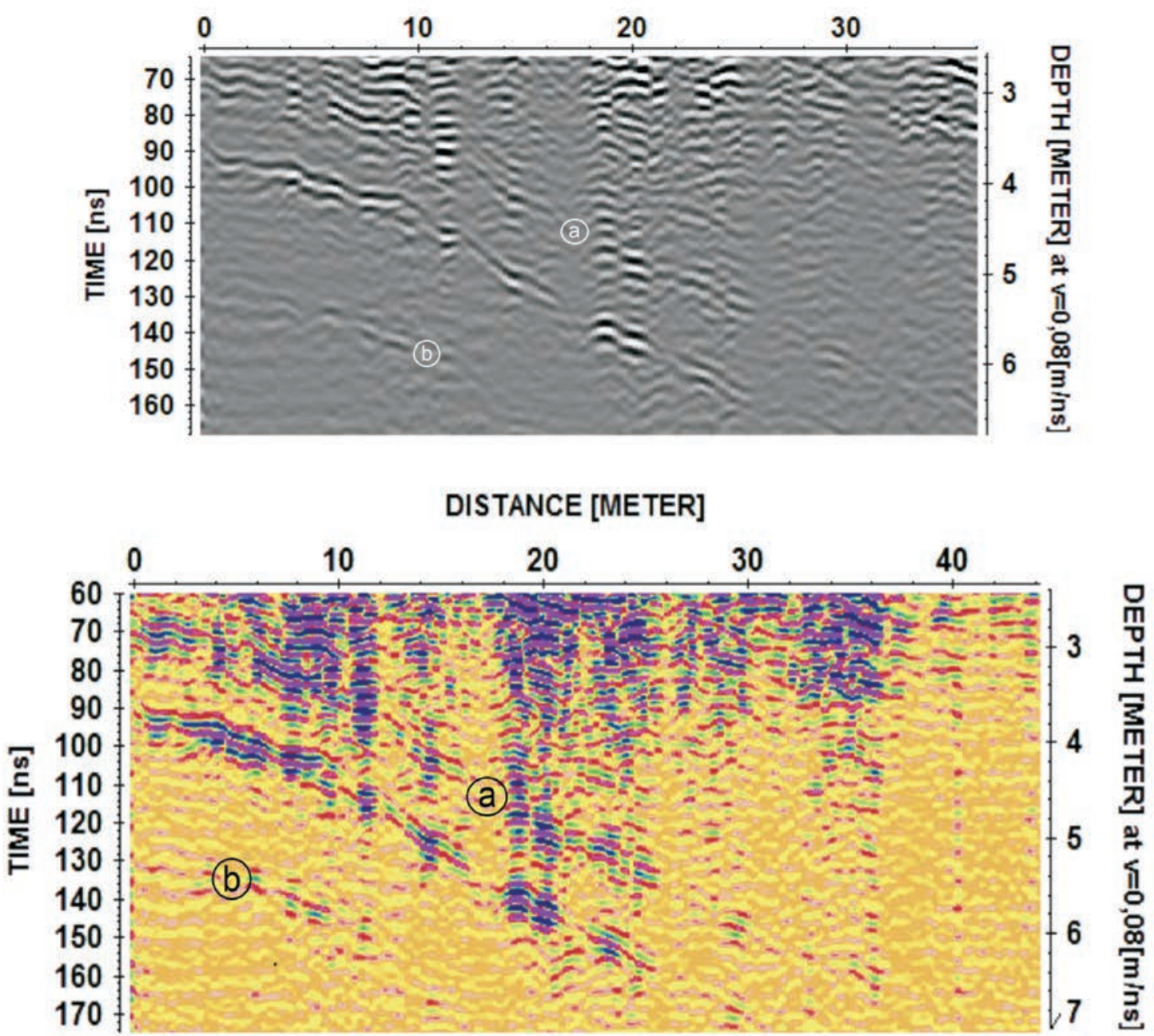

Fig. 7. Echogram G. 7, antenna $500 \mathrm{MHz}$, with close up of its northwestern section. $\mathrm{a}$ - upper flint layer, $\mathrm{b}$ - lower flint layer.

\section{CONCLUSIONS}

The data obtained during prospection of the prehistoric mining field at Borownia confirmed usefulness of 100, 250 and $500 \mathrm{MHz}$ antennas in such research. Relatively large range of depth and good resolution were due to favorable geological conditions. The Upper Jurassic pelitic limestones were the medium that absorbed slightly the electromagnetic waves.

The research allowed identifying geology of the Borownia mining field. Acquired radiograms revealed three distinct zones with concentration of anomalies in the studied area (Fig. 11). While the central zone (B) was clearly a fragment of the prehistoric mining field, that was confirmed not only by GPR sounding but also by archeological surveys, the other two have not been identified yet. In the other two zones, the further detailed geoarchaeological studies may determine only whe- ther the underground structures are of natural origin or they have been created by humans.

A flint layer exploited in prehistoric times in the area B runs NW-SE and dips at approximately 15 degrees towards northeast. Such geological structure determined manner of flint exploitation by prehistoric miners, similar to the prehistorical mine complex at Krzemionki Opatowskie. The ex- 

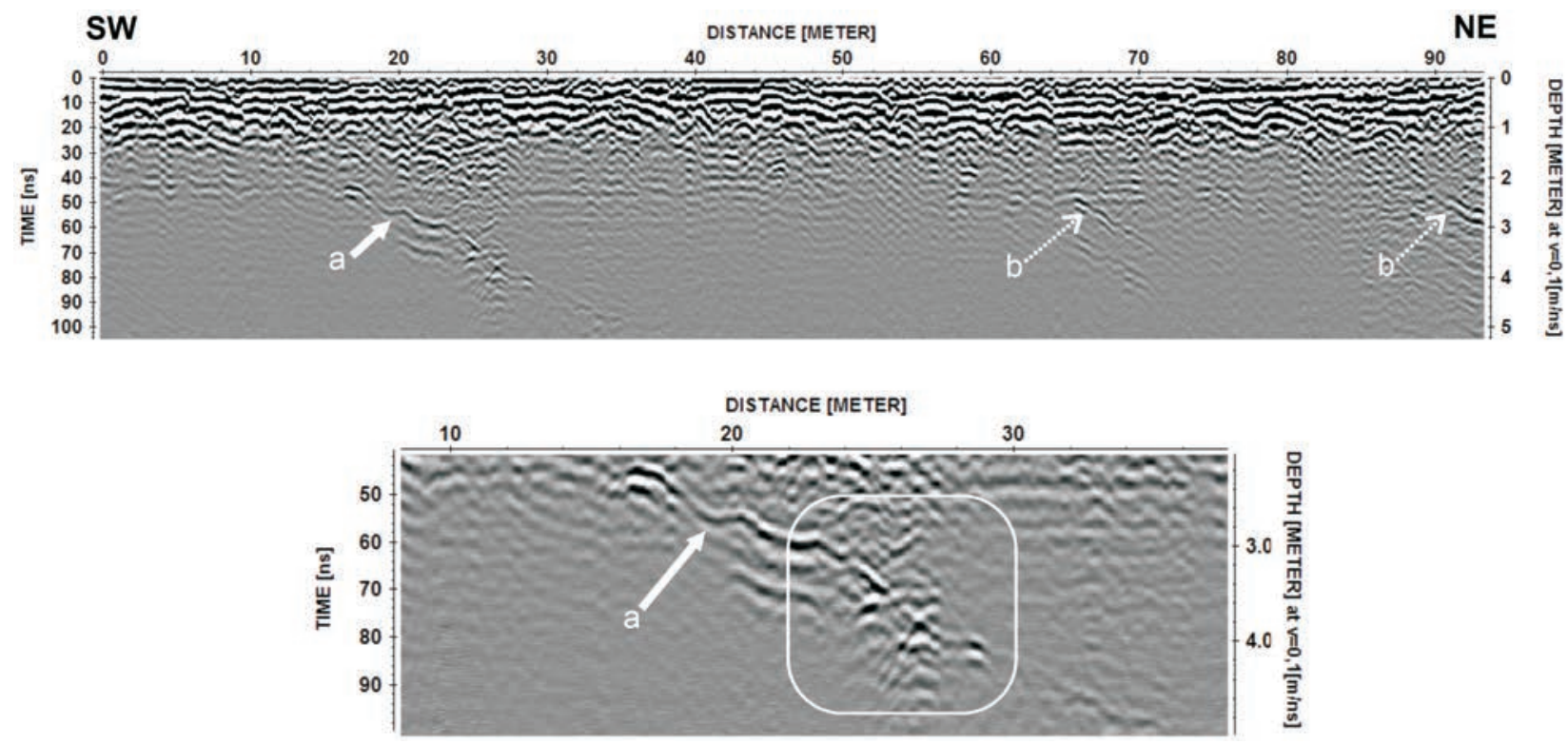

Fig. 8. Echogram G. 3, zone C, antenna $500 \mathrm{MHz}$. a - flint layer ?, b - other lithological boundaries (stratification).
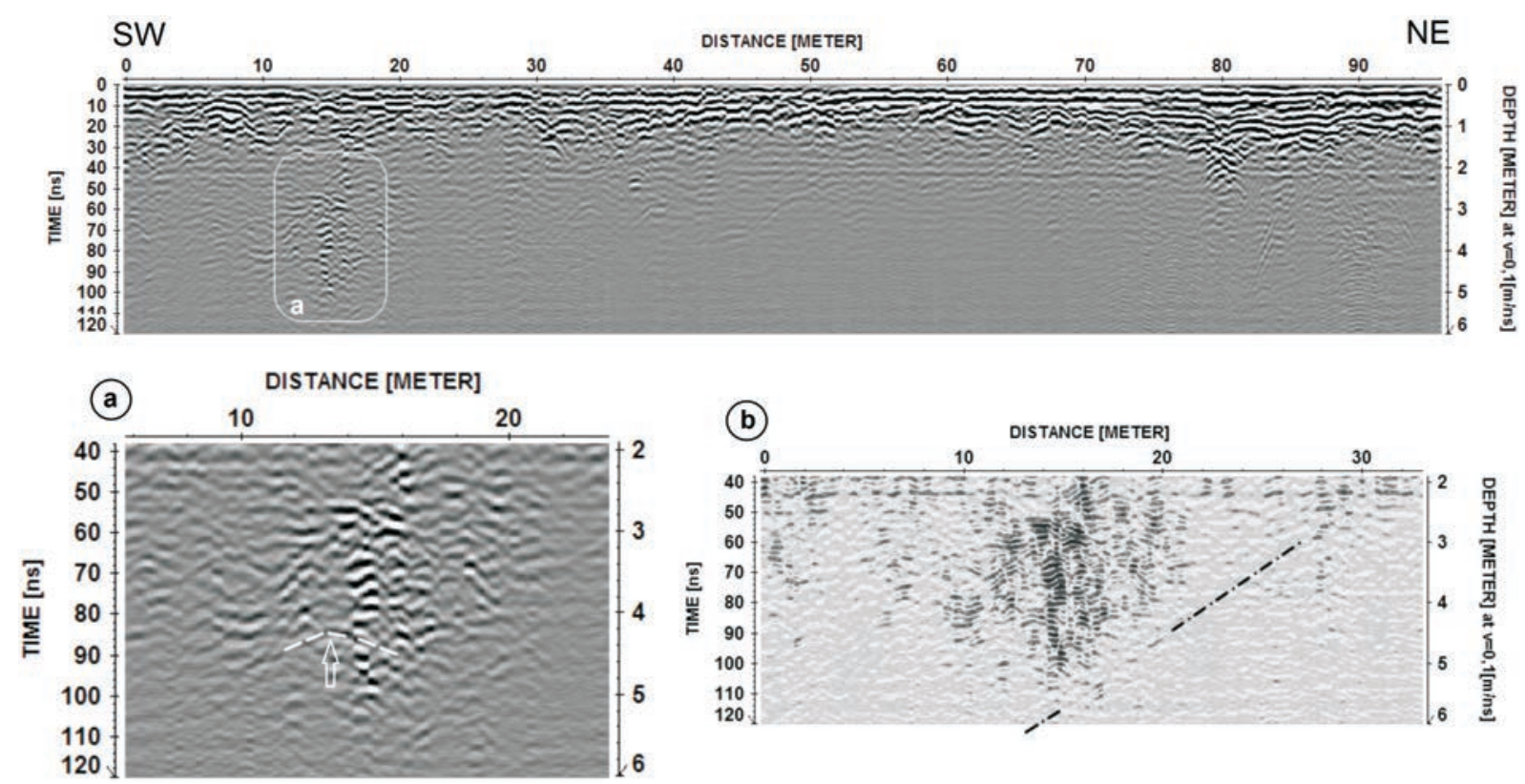

Fig. 9. Echogram G. 4, antenna 500 MHz. a - echo of the mineshaft? The vertical arrow indicates a roof of the rock void (gallery?). Dashed line points explored flint layer in prehistoric time.

ploited rock layers were inclined what resulted in different depth of mining structures, as already determined in the northwestern part of the mining field at Borownia. Objects located close to the outcrop of the flint layer were shallower; those situated farther were deeper (cf. Welc et al., 2014).

Results of geophysical survey solely did not enable determination of the chronology of prehistorical mining activities in particular zones of the mining field at Borownia. It was also not possible either to state which flint layer was exploited at that time. Based on the example of Krzemionki Opatowskie, one could conclude only that flint nodules centered in regular layers were the focus of the Neolithic miners. Disperse raw material was not exploited, because it would not be a profitable process (Sałaciński and Michniak, 1992).

\section{REFERENCES}

Balcer, B., Kowalski, K. 1978. Z badań nad krzemieniem pasiastym w pradziejach. Wiadomości Archeologiczne 43: 127-145.

Borkowski, W. 1995 Krzemionki Mining Complex. Deposit Management System. Studia nad gospodarką surowcami krzemiennymi w pradziejach 2. Państwowe Muzeum Archeologiczne. Warszawa.

Borkowski, W. 2000. Metody badania systemu zagospodarowania złoża krzemienia w pradziejach. In: W. Borkowski (Ed.), Metody badań archeologicznych stanowisk produkcyjnych górnictwo krzemienia. Warszawa.

Borkowski, W., Michniak. R. 1992. Prahistoryczne pole eksploatacyjne (wybierkowe) w Krzemionkach. Materiały Krzemionkowskie, Studia nad gospodarką surowcami krzemiennymi w 

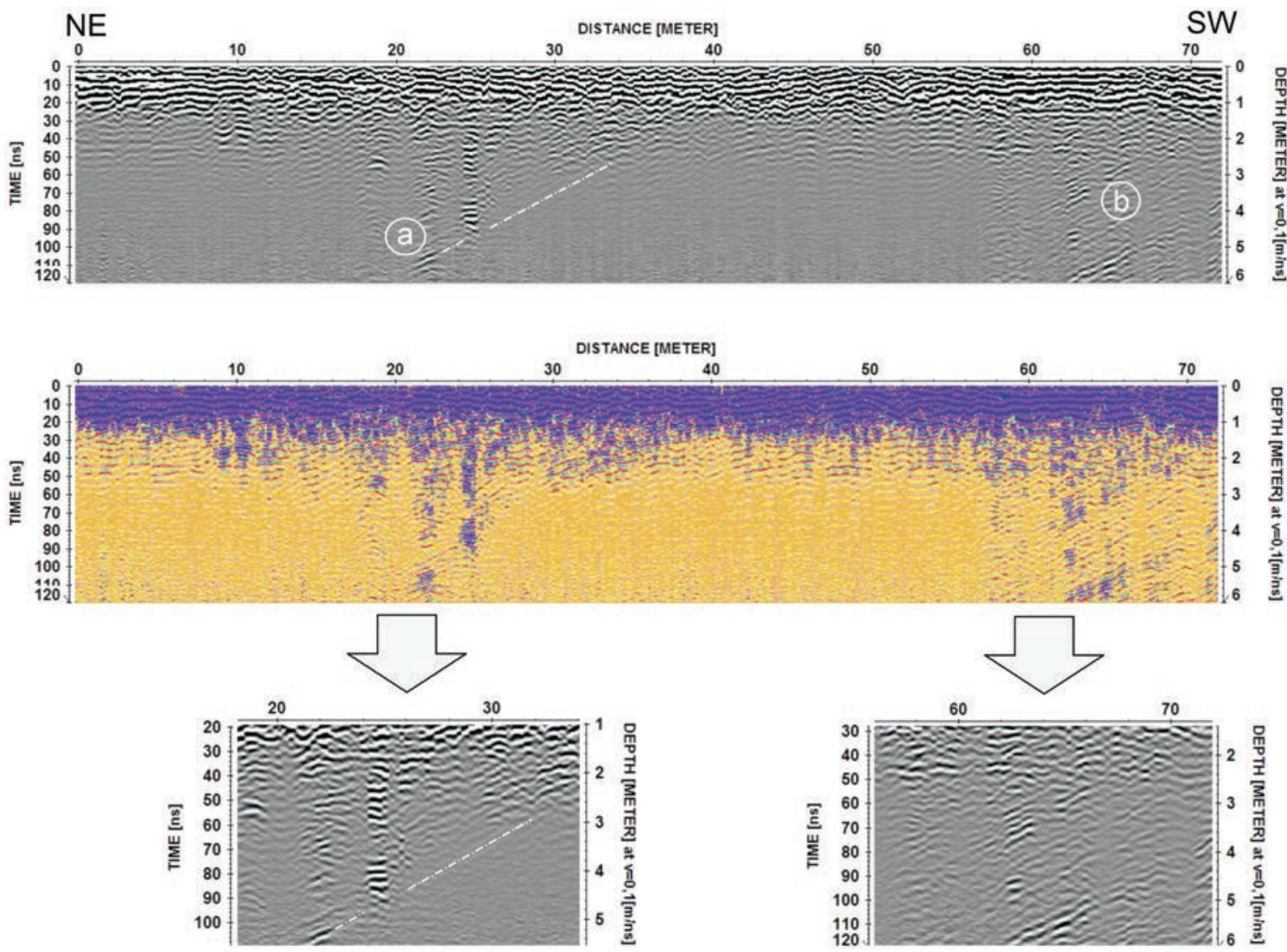

Fig. 10. Echogram G. 6, antenna $500 \mathrm{MHz}$. a - echo of the mineshaft (dashed line points explored flint layer), b-stratification of the limestone massif.

pradziejach. Warszawa: 11-37.

Boubaki, N., Saintenoy, A., Kowalczyk, S., Mieszkowski, R., Welc, F., Budziszewski, J., Tucholka, P. 2012. Ground-penetrating radar prospection over a gallery network resulting from Neolithic flint mine (Borownia, Poland). In: Proceedings of the 14th International Conference on Ground Penetrating Radar (GPR), June 4-8, 2012. Shanghai: 610-615.

Budziszewski J., Michniak, R. 1983/1989. Z badań nad występowaniem, petrograficzną naturą oraz prahistoryczną eksploatacją krzemieni pasiastych w południowym skrzydle niecki Magoń-Folwarczysko. Wiadomości Archeologiczne 49/2: 151-190.

Budziszewski, J. 2008. Stan Badań nad występowaniem i pradziejową eksploatacją krzemieni czekoladowych. In: red. Borkowski, W., Libera, J., Sałacińska, B., Sałaciński, S. (Eds.), Krzemień czekoladowy w pradziejach, Studia nad gospodarką surowcami krzemiennymi w pradziejach 7 . Warszawa - Lublin: 33-106.

Conyers, L.B. 2004. Ground Penetrating Radar for Archaeology. Altamira Press, Walnut Creek, California.

Davis, J.L., Annan, A.P. 1989. Ground-Penetrating Radar for highresolution mapping of soil and rock stratigraphy. Geophysical Prospecting, 37: 531-551.

Gutowski, J. 1998. Oxfordian and Kimmeridgian of the northeastern margin of the Holy Cross Mountains, Central Poland. Geological Quarterly, 41(1): 59-72.

Jaroszewski, W. 1972. Drobnostrukturalne kryteria tektoniki obszarów miorogenicznych na przykładzie północno-wschodniego obrzeżenia mezozoicznego Gór Świętokrzyskich. Studia Geologica Polonica, 38: 1-215.

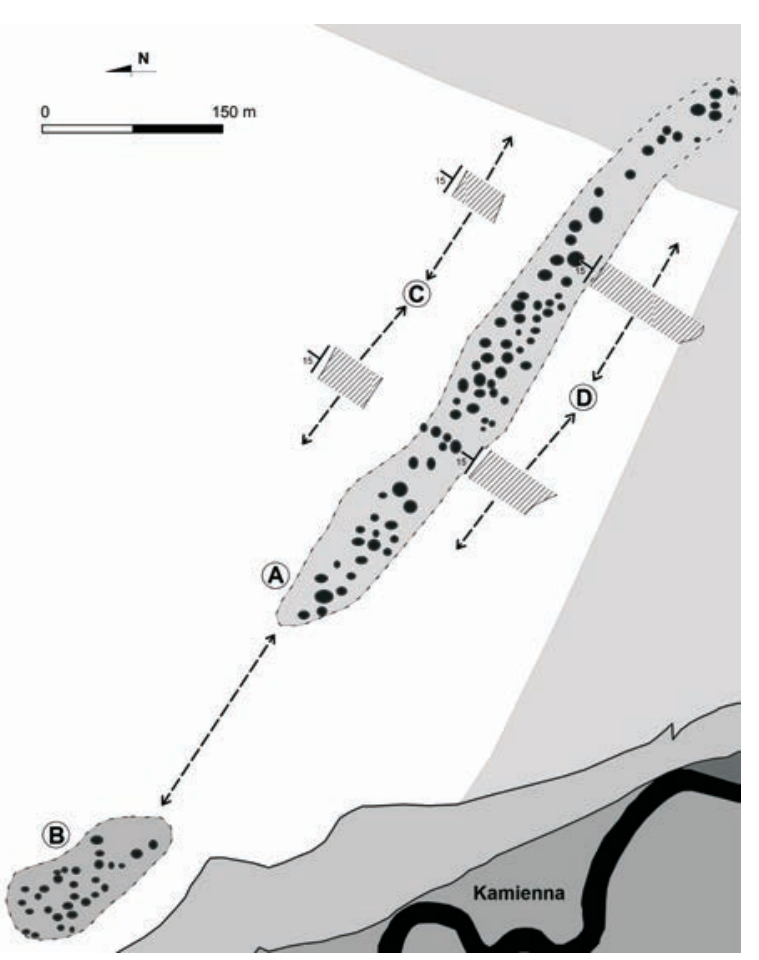

Fig. 11. The GPR survey of the prehistoric mining field at Borownia. Acquired radiograms reveal three distinct zones of anomalies' concentration: the zones A-B are a fragment of the prehistoric mining field, the zones $\mathrm{C}$ and $\mathrm{D}$ have not been identified yet. 
Karczewski, J. 2007. Zarys metody georadarowej. Kraków. Klimaszewski, M. 1978. Geomorfologia. Warszawa.

Krukowski, S. 1921. Sprawozdanie z działalności państwowego urzędu konserwatorskiego na okręg warszawski południowy. Wiadomości Archeologiczne, 6: 156-167.

Romanek, A. 1994. Objaśnienia do szczegółowej mapy geologicznej Polski, arkusz Ostrowiec Świętokrzyski (818), 1:50 000. Warszawa.

Sałaciński, S., Michniak, R. 1992. Wyniki badań prowadzonych w północnej partii pola eksploatacyjnego w Krzemionkach. Materiały Krzemionkowskie, Studia nad gospodarką surowcami krzemiennymi w pradziejach. Warszawa.

Samsonowicz, J. 1934a. Ogólna Mapa Geologiczna Polski w skali 1:100 000, arkusz Opatów. Warszawa.

Samsonowicz, J. 1934b. Objaśnienia arkusza Opatów ogólnej mapy geologicznej Polski w skali 1:100 000. Warszawa.

Welc, F., Mieszkowski, R., Budziszewski, J., Wysocki, J., Kowalczyk, S., Nalazek, C. 2014. Przydatność metody georadarowej(GPR) w nieinwazyjnej prospekcji archeologicznej na przykładzie trzech typów stanowisk z obszaru Polski, Fontes 49: in print. 